\title{
PENGEMBANGAN SISTEM PENDAFTARAN ONLINE CALON PESERTA PPL DAN KKN FKIP UNTAN
}

\author{
Rahmat Rasmawan ${ }^{1 *}$, Tomo Djudin ${ }^{2}$ \\ ${ }^{1,2}$ Fakultas Keguruan dan Ilmu Pendidikan Universitas Tanjungpura, Jalan Prof. Dr. H. Hadari Nawawi \\ Pontianak Kalimantan Barat Indonesia \\ *email: rahmatfkip@gmail.com
}

\section{Received: 26 Maret 2019 Accepted: 1 Juni 2019 Published: 30 Juni 2019}

\begin{abstract}
Abstrak
Penelitian ini bertujuan untuk mengembangkan website pendaftaran kegiatan Praktek Pengenalan Lapangan (PPL) dan Kuliah Kerja Nyata (KKN) mahasiswa FKIP Untan yang valid dan layak digunakan. Jenis penelitian yang digunakan adalah Research and Development $(R \& D)$ dengan model System Development Life Cycle (SDLC) dengan bentuk waterfall yang memiliki empat tahapan, yaitu Analysis, Design, Coding dan Testing. Alat pengumpul data adalah lembar validasi penilaian dan angket respon pengguna website. Hasil penelitian menunjukkan bahwa website yang dikembangkan valid dan layak digunakan ditinjau dari tampilan, proses pendaftaran, kemudahan akses dan pertahanan sistem dari virus dan pembobolan data serta pengguna memberikan respon positif yang tinggi dari penggunaan website dalam proses pendaftaran. Sehingga dapat disimpulkan bahwa website yang dikembangkan valid dan layak digunakan dalam proses pendaftaran peserta PPL dan KKN.
\end{abstract}

Kata kunci: sistem pendaftaran online, praktek pengenalan lapangan (PPL), kuliah kerja nyata (KKN)

\begin{abstract}
This research aims to develop a registration website for Field Recognition Practice activities (PPL) and Real Work Lectures (KKN) for students of FKIP Untan which are valid and worthy of use. The type of research used is Research and Development $(R \& D)$ with the System Development Life Cycle (SDLC) model with a waterfall form that has four stages, namely Analysis, Design, Coding, and Testing. Data collection tools are assessment validation sheets and website user response questionnaires. The results showed that the website developed is valid and possible to use in terms of appearance, registration process, ease of access and system defense from viruses and data breaching and users gave a high positive response from website usage in the registration process. Based on the results obtained it concluded that the website developed is valid and possible to use in the PPL and KKN participant registration process.
\end{abstract}

Keywords: registration website, field recognition practice activities (PPL), real work lectures (KKN)

(C) 2019 LPPM IKIP PGRI Pontianak, Indonesia

\section{PENDAHULUAN}

Kehadiran internet dalam teknologi informasi dan komunikasi membantu aktivitas masyarakat dalam memperoleh dan menyampaikan informasi secara cepat. Internet juga mendorong terjadinya keragaman gaya hidup dan penampilan untuk memicu kreatifitas dan ide- 
ide yang baru. Dalam dunia pendidikan, Teknologi informasi dan komunikasi juga berperan dalam mempermudah pengurusan administrasi akademik, pendaftaran maupun proses belajar mengajar. Komunikasi sebagai media pendidikan dapat dilakukan menggunakan media-media komunikasi seperti telepon, komputer, internet, email dan sebagainya. Implementasi teknologi informasi dan komunikasi diperlukan mulai dari tahap perencanaan, pelaksanaan dan pengawasan program-program pembangunan disegala bidang.

Unit Pembelajaran FKIP Untan adalah suatu unit pada Fakultas Keguruan dan Ilmu Pendidikan Universitas Tanjungpura yang bertugas untuk mengelolah kegiatan Program Micro Teaching, Pengenalan Lapangan (PPL), dan Kuliah Kerja Nyata (KKN semuanya merupakan mata kuliah wajib seluruh program studi di lingkungan FKIP Untan. Pengelolahan yang dilakukan Unit Pembelajaran dimulai dari tahap pendaftaran, verifikasi, penentuan jadwal pelaksanaan, pembekalan, pengolahan nilai dan laporan hasil kegiatan kepada pimpinan fakultas (Dekan). Peserta yang mengikuti kegiatan Micro Teaching, PPL dan KKN tergolong jumlah yang besar, secara rinci disajikan pada Tabel 1.

Tabel 1. Jumlah Peserta Kegiatan PPL dan KKN FKIP Untan

\begin{tabular}{lccc}
\hline \multirow{2}{*}{ Kegiatan } & \multicolumn{3}{c}{ Tahun Pelaksanaan } \\
& 2015 & 2016 & 2017 \\
\hline PPL II & 1324 & 1341 & 1512 \\
KKN & 1324 & 1345 & 1451 \\
\hline
\end{tabular}

Kegiatan Program Pengenalan Lapangan (PPL) dan KKN dilakukan pada semester tujuh. Alur kerja Unit Pembelajaran pada pelaksanaan PPL dan KKN dimulai dari penentuan jadwal pembukaan pendaftaran. Mahasiswa yang ingin mengikuti program PPL dan KKN datang mendaftar ke unit pembelajaran. Selanjutnya mahasiswa mengambil formulir pendaftaran serta mengisi biodata peserta dan melengkapi persyaratan yang telah ditentukan. Selanjutnya verifikasi berkas pendaftaran mahasiswa yang dilakukan Unit Pembelajaran. Pada tahap ini mahasiswa mengantri satu persatu kepada petugas Unit Pembelajaran untuk mengecek berkas syarat-syarat pendaftaran. Apabila mahasiswa tidak memenuhi atau memiliki persyaratan yang belum lengkap, maka mereka harus melengkapkan terlebih dahulu persyaratan tersebut. Setelah terkumpul data mahasiswa yang mengikuti kegiatan PPL dan KKN, selanjutnya Unit Pembelajaran menginput satu persatu nama peserta yang lulus persyaratan dan selanjutnya 
membagi kelompok KKN dan PPL untuk ditempatkan di tempat tujuan KKN dan sekolah mitra pada kegiatan PPL.

Pelayanan unit pembelajaran yang dirasakan sangat kurang adalah pada saat pendaftaran kegiatan PPL dan KKN. Hal ini disebabkan karena keterbatasan waktu jam kerja Unit Pembelajaran dengan jadwal perkuliahan mahasiswa (peserta kegiatan). Mahasiswa dapat mendaftar apabila terdapat jam kosong perkuliahan dan berakibat penumpukan peserta pendaftaran pada jam-jam tertentu. Hal ini menyebabkan antrian yang panjang dan memakan waktu yang lama untuk setiap mahasiswa dikarenakan adanya tahap verifikasi berkas persyaratan.

Dampak dari proses pendaftaran yang dilakukan menyebabkan proses pendaftaran dibuka dengan alokasi waktu yang cukup lama, biasanya dua sampai tingga minggu hanya untuk menyediakan waktu pendaftaran. Karena proses pendaftaran yang relatif lama sehingga menyebabkan pengimputan nama peserta dan pembagian kelompok juga terhambat. Akibatnya proses kegiatan yang seharusnya berada pada awal semester dapat mundur sampai satu atau dua bulan dari awal semester perkuliahan.

Berdasarkan paparan di atas, perlu dilakukan usaha mempermudah proses pendaftaran dan verifikasi persyaratan. Salah satunya dengan mengembangkan sistem online pendaftaran kegiatan PPL dan KKN yang dikelolah oleh Unit Pembelajaran. Sistem online dapat mengurangi waktu pendaftaran dan mempersingkat verifikasi persyaratan sehingga mahasiswa dapat melaksanakan kegiatan PPL dan KKN tepat pada waktu yang ditentukan.

\section{METODE}

Penelitian ini bertujuan untuk mengembangkan web pendaftaran kegiatan PPL dan KKN bagi mahasiswa FKIP Untan sehingga bentuk penelitian yang digunakan adalah Research and Development (R\&D). Model pengembangan web yang digunakan adalah model System Development Life Cycle (SDLC) dengan bentuk waterfall. Adapun tahapan pengembangan sistem web mengikuti alur dari Youssef (2012) dapat dilihat pada Gambar 1. Setelah dihasilkan web pendaftaran kegiatan PPL dan KKN, selanjutnya divalidasi oleh pakar bidang IT (Informasi dan Teknologi) oleh UPT TIK FKIP Untan. Setelah dinyatakan valid, selanjutnya dilakukan uji coba terhadap peserta kegiatan PPL dan KKN tahun ajaran 2018/2019 untuk mengetahui kemudahan, ketepatan dan respon pengguna. 


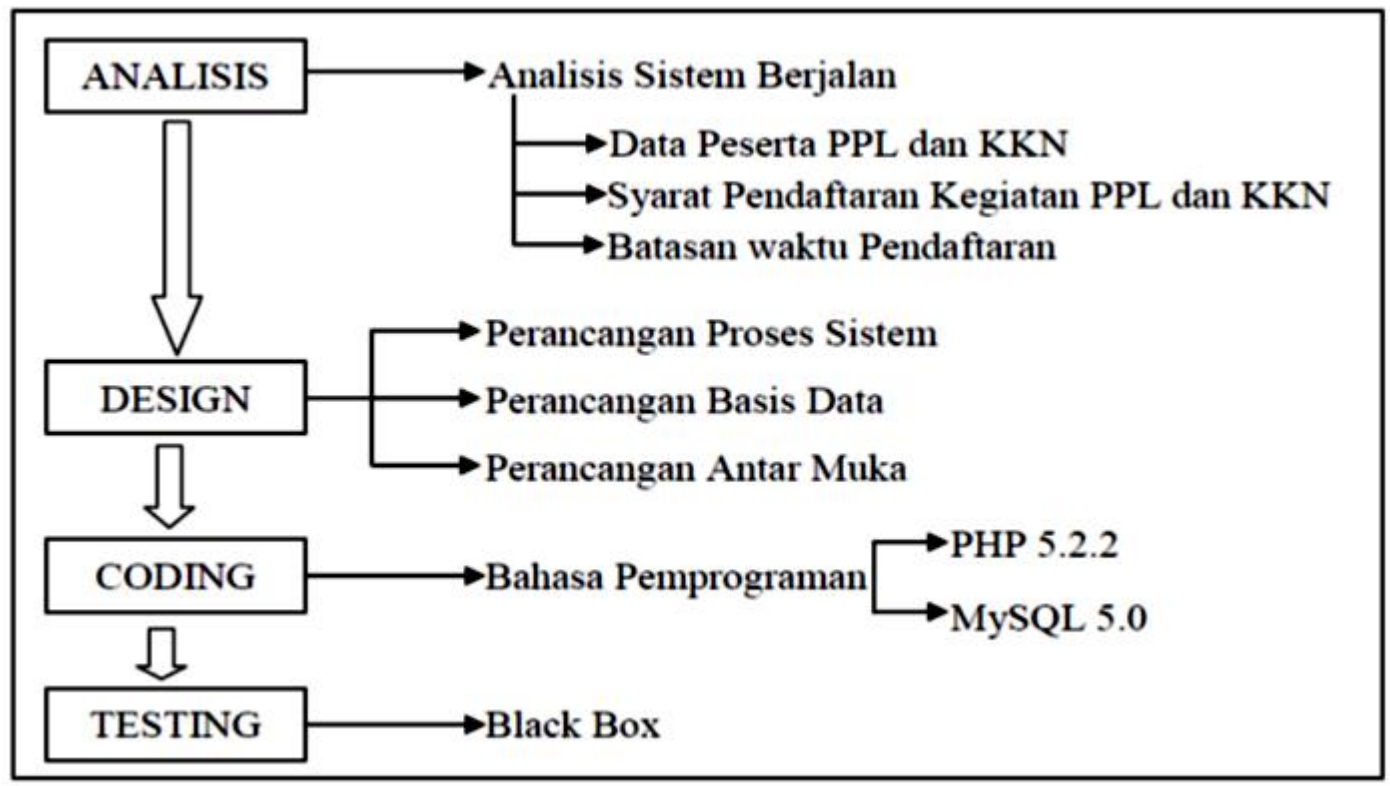

Gambar 1. Alur penelitian pengembangan web pendaftaran PPL dan KKN

Alat pengumpul data dalam penelitian ini adalah lembar validasi, pedoman wawancara dan angket respon penggunaan web pendaftaran kegiatan PPL dan KKN. Lembar validasi digunakan untuk melihat kesesuaian antara web dengan tahapan pendaftaran, kemudahan akses peserta, pertahanan sistem web dari virus dan pembobol data. Pedoman wawancara digunakan untuk melihat tanggapan, saran dan masukkan dari validator tentang web yang dikembangkan. Angket respon digunakan untuk melihat tanggapan pengguna web (peserta PPL dan KKN) tentang kemudahan akses dan penggunaan web dalam proses pendaftaran.

Data yang diperoleh selanjutnya dianalisis secara kuantitatif. Hasil validasi yang dilakukan oleh validator ditentukan rata-rata penilaian kelayakan terhadap web yang dikembangkan. Angket respon mahasiswa dianalisis dengan menggunakan skala linkert dengan tanggapan sangat setuju, setuju, kurang setuju dan tidak setuju yang telah dikembangkan. Saran dan masukkan dari validator dideskripsikan secara kualitatif dalam memperbaiki situs web yang dikembangkan.

\section{HASIL DAN PEMBAHASAN}

\section{Tahap Pengembangan Web}

Tahap pertama dalam pengembangan web pendaftaran peserta PPL dan KKN di FKIP Untan diawali dengan tahap analisis, yaitu analisis sistem berjalan. Pengumpulan data peserta 
dilakukan dengan sinkronisasi data SIAKAD Untan terkait dengan data Nama, Nomor Induk Mahasiswa (NIM), Program Studi, Indeks Prestasi Komulatif (IPK), Indeks Prestasi Semester (IPS) dan Lembar Isian Hasil Studi (LIHS). Data-data tersebut digunakan sebagai dasar melalukan verifikasi persyaratan peserta kegiatan PPL dan KKN. Selanjutnya pada tahap ini ditentukan syarat peserta PPL dan KKN. Persyaratan kegiatan PPL adalah telah lulus mata kuliah Micro Teaching dan untuk kegiatan KKN apabila mahasiswa telah menempuh mata kuliah sebesar 90 sks.

Setelah dilakukan analisis sistem berjalan, selanjutnya mendesain web. Rancangan sistem menggunakan Diagram Use Case yang dapat dilihat pada Gambar 2. Selanjutnya dirancanglah basis data dengan menggunakan phpmyadmin pada sofware xampp. Menurut Standsyah dan Restu (2017) phpmyadmin adalah alat untuk mempermudah pengoperasian data base, yaitu mengelolah dan mengatur data di MySQL. Selanjutnya didesain antar muka antara komputer pemakain sistem (peserta dan administrator) yang terdiri dari proses memasukkan data ke sistem, menampilkan input-output informasi kepada user dan sebaliknya. Tampilan antar muka dapat dilihat pada bagian simulasi web.

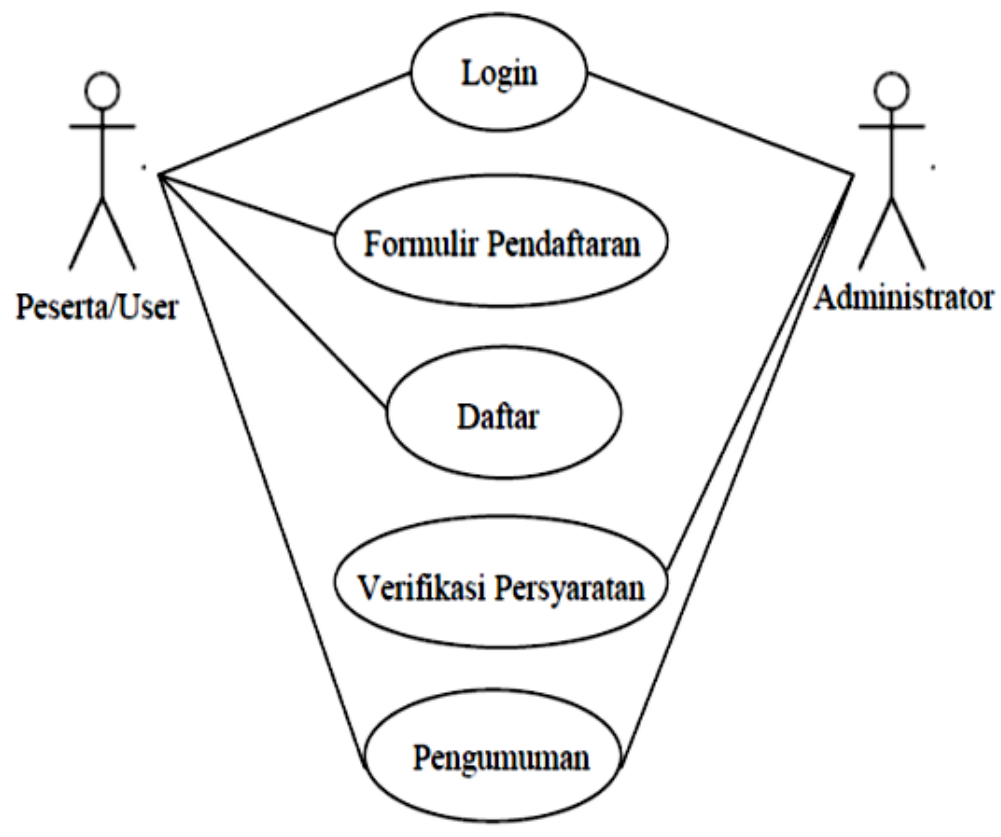

Gambar 2. Diagram use case sistem pendaftaran

Tahap selanjutnya adalah coding (pengkodean) dengan bahasa pemprograman php dan MySQL. Selanjutnya, dilakukan testing pada fungsi eksternal (black-box). Menurut Alfaris, Anam \& Masy’an (2013) Black Box Testing digunakan untuk mengetes program langsung 
dengan melihat padaaplikasinya tanpa perlu mengetahui struktur programnya sehingga mudah ditemukan kesalahan serta memastikan output yang dihasilkan sesuai dengan yang diinginkan pada tahap perancangan web. Hasil pada tahap testing disajikan pada Tabel 2. Berdasarkan hasil testing diketahui bahwa semua fungsi berjalan dengan baik dan dapat digunakan oleh pengguna web.

Tabel 2. Hasil testing menggunakan black-box

\begin{tabular}{|c|c|c|c|}
\hline No & Uji Kasus & Harapan & Hasil \\
\hline 1 & $\begin{array}{l}\text { Login } \\
\text { Pendaftar }\end{array}$ & $\begin{array}{l}\text { Mahasiswa peserta kegiatan PPL dan KKN dapat login } \\
\text { menggunakan sandi SIAKAD Untan }\end{array}$ & ok \\
\hline 2 & $\begin{array}{l}\text { Formulir } \\
\text { Pendaftaran }\end{array}$ & $\begin{array}{l}\text { Mahasiswa dapat mengisi formulir pendaftaran, antara lain } \\
\text { jenis kelamin, alamat tempat tinggal dan email aktif }\end{array}$ & ok \\
\hline 3 & Daftar & $\begin{array}{l}\text { Mahasiswa dapat mendaftar kegiatan PPL atau KKN yang } \\
\text { dipilihnya }\end{array}$ & ok \\
\hline 4 & $\begin{array}{l}\text { Login } \\
\text { Administrator }\end{array}$ & $\begin{array}{l}\text { Admin kegiatan PPL dan KKN dapat login menggunakan } \\
\text { sandi untuk mengecek jumlah pendaftar }\end{array}$ & ok \\
\hline 5 & $\begin{array}{l}\text { Verifikasi } \\
\text { pendaftaran }\end{array}$ & $\begin{array}{l}\text { Admin dapat memverifikasi pendaftaran dengan sinkroninasi } \\
\text { data SIAKAD, } \\
\text { Persyaratan PPL apabila telah lulus mata kuliah Micro } \\
\text { Teaching yang diketahui dari LIHS pada data SIAKAD } \\
\text { Untan. } \\
\text { Persyaratan KKN apabila telah menempuh minimal } 90 \\
\text { SKS }\end{array}$ & ok \\
\hline 6 & Pengumuman & $\begin{array}{l}\text { Admin menyatakan kelulusan sebagai peserta kegiatan PPL } \\
\text { dan KKN ke dalam web dan pesan ke email pendaftar } \\
\text { Pendaftar mengetahui kelulusannya sebagai peserta kegiatan } \\
\text { PPL dan KKN melalui web dan email }\end{array}$ & ok \\
\hline
\end{tabular}

\section{Simulasi Hasil Pembuatan Web Pendaftaran}

Web pendaftaran dapat diakses melalui https://unitpembelajaran.fkip.untan.ac.id/login. Penggunaan web ini terdiri dari dua tampilan tatap muka, yaitu pendaftar kegiatan dan administrator. Tampilan login antara pendaftar dan administrator memiliki tampilan muka yang sama pada saat login, seperti yang disajikan pada Gambar 3. 


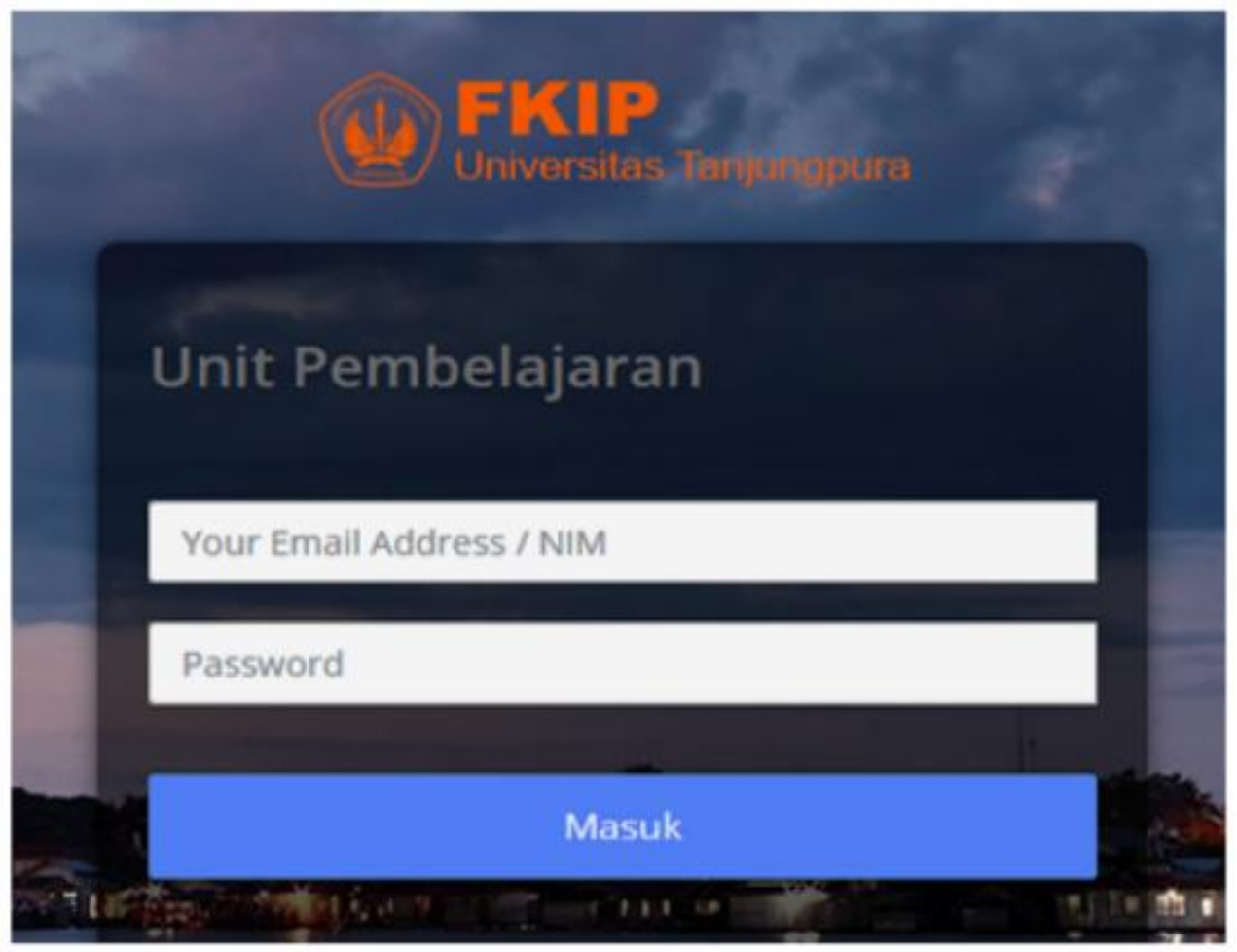

Gambar 3. Tampilan login pendaftar dan administrator

Tampilan muka apabila pendaftar berhasil login disajikan pada Gambar 4. Tampilan ini berisikan data nama mahasiswa, NIM, Program Studi, IPK dan IPS yang merupakan hasil sinkronisasi dengan data SIAKAD UNTAN.

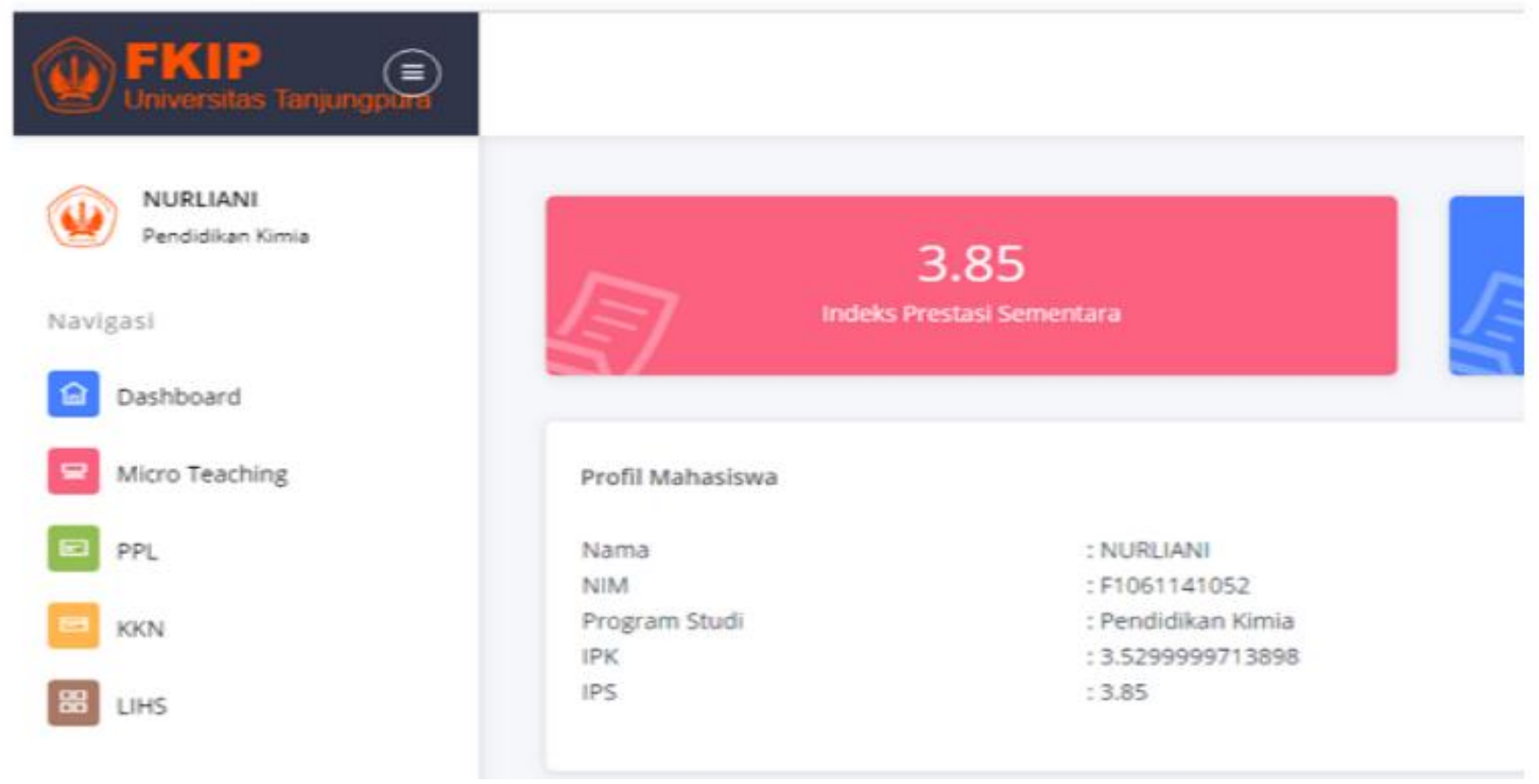

Gambar 4. Tampilan setelah pendaftar berhasil login 
Tampilan muka pada proses pendaftaran kegiatan PPL disajikan pada Gambar 5. Tampilan berisikan data yang harus diisi pendaftar, meliputi tempat tanggal lahir, kelas regular atau PPAPK, alamat tempat tinggal dan nomor HP. Jika telah selesai mengisi data selanjutnya dilakukan pendaftaran dan menunggu hasil verifikasi oleh administrator.

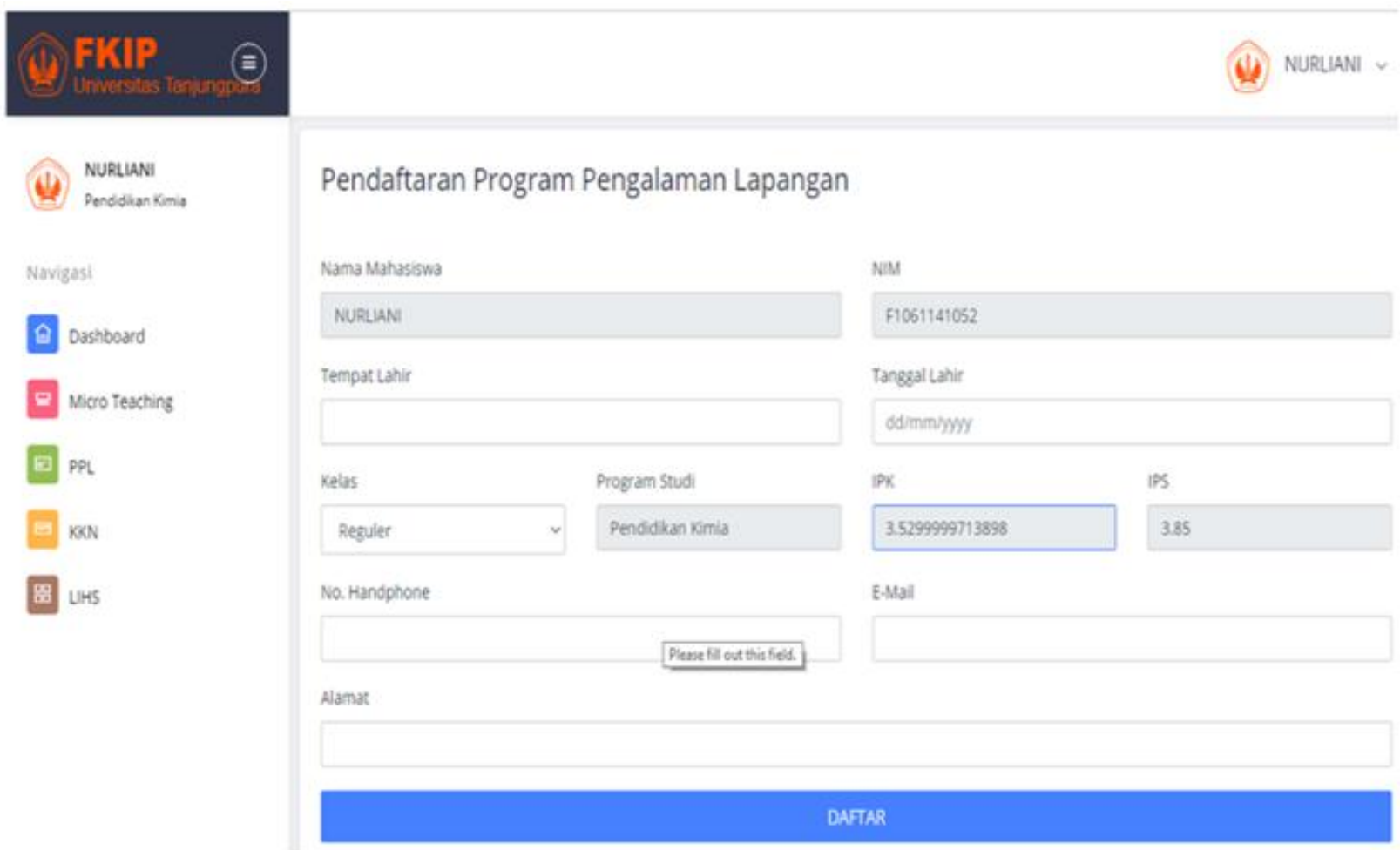

Gambar 5. Tampilan saat proses proses pendaftaran peserta PPL

Tampilan muka proses pendaftaran kegiatan KKN disajikan pada Gambar 6. Tampilan berisikan data yang harus diisi pendaftar, meliputi tempat tanggal lahir, kelas regular atau PPAPK, alamat tempat tinggal dan nomor HP. Jika telah selesai mengisi data selanjutnya dilakukan pendaftaran dan menunggu hasil verifikasi oleh administrator. 


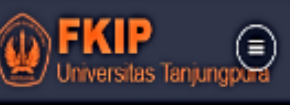

\begin{tabular}{|c|c|}
\hline 1 & $\begin{array}{l}\text { NURLAANI } \\
\text { Pand ditan Kimis }\end{array}$ \\
\hline Nav & yasi \\
\hline & Dashboard \\
\hline & Micro Teaching \\
\hline E & $\mathrm{PPL}$ \\
\hline & $\mathrm{K}<\mathrm{N}$ \\
\hline & LIIS \\
\hline
\end{tabular}

Pendaftaran Kuliah Kerja Nyata

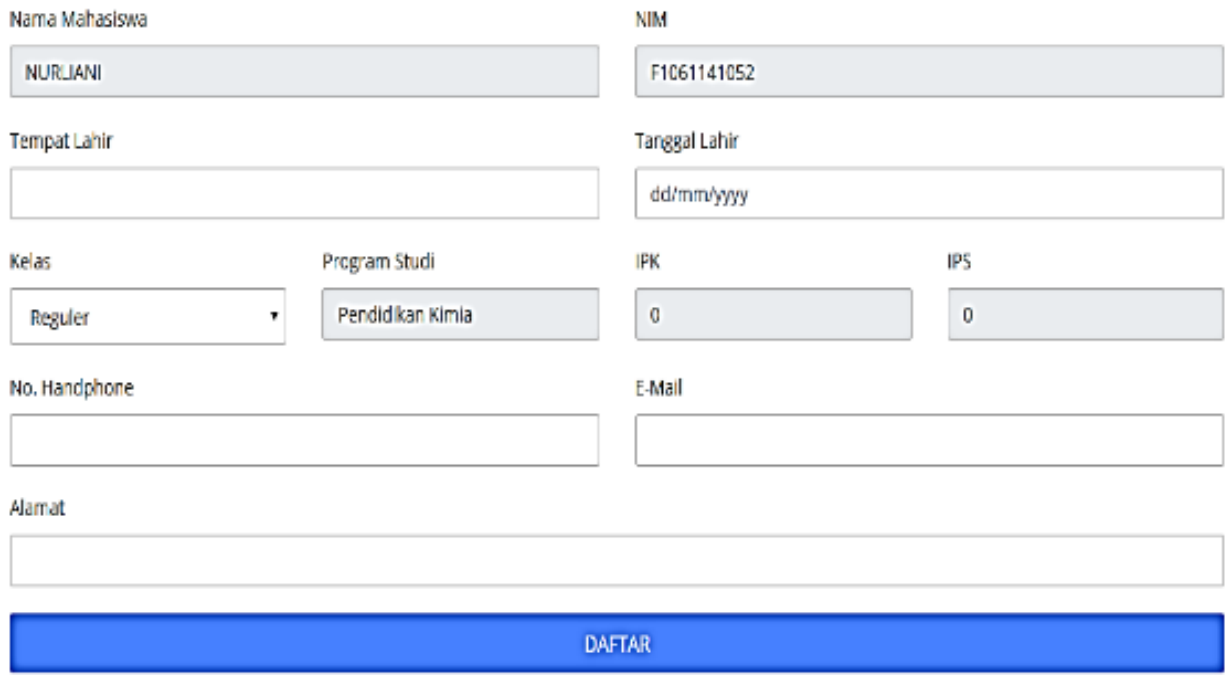

Gambar 6. Tampilan saat proses pendaftaran KKN

Tampilan muka pada saat verifikasi pendaftaran oleh administrator disajikan pada Gambar 7. Tampilan ini berisikan data mahasiswa sebagai pendaftar.

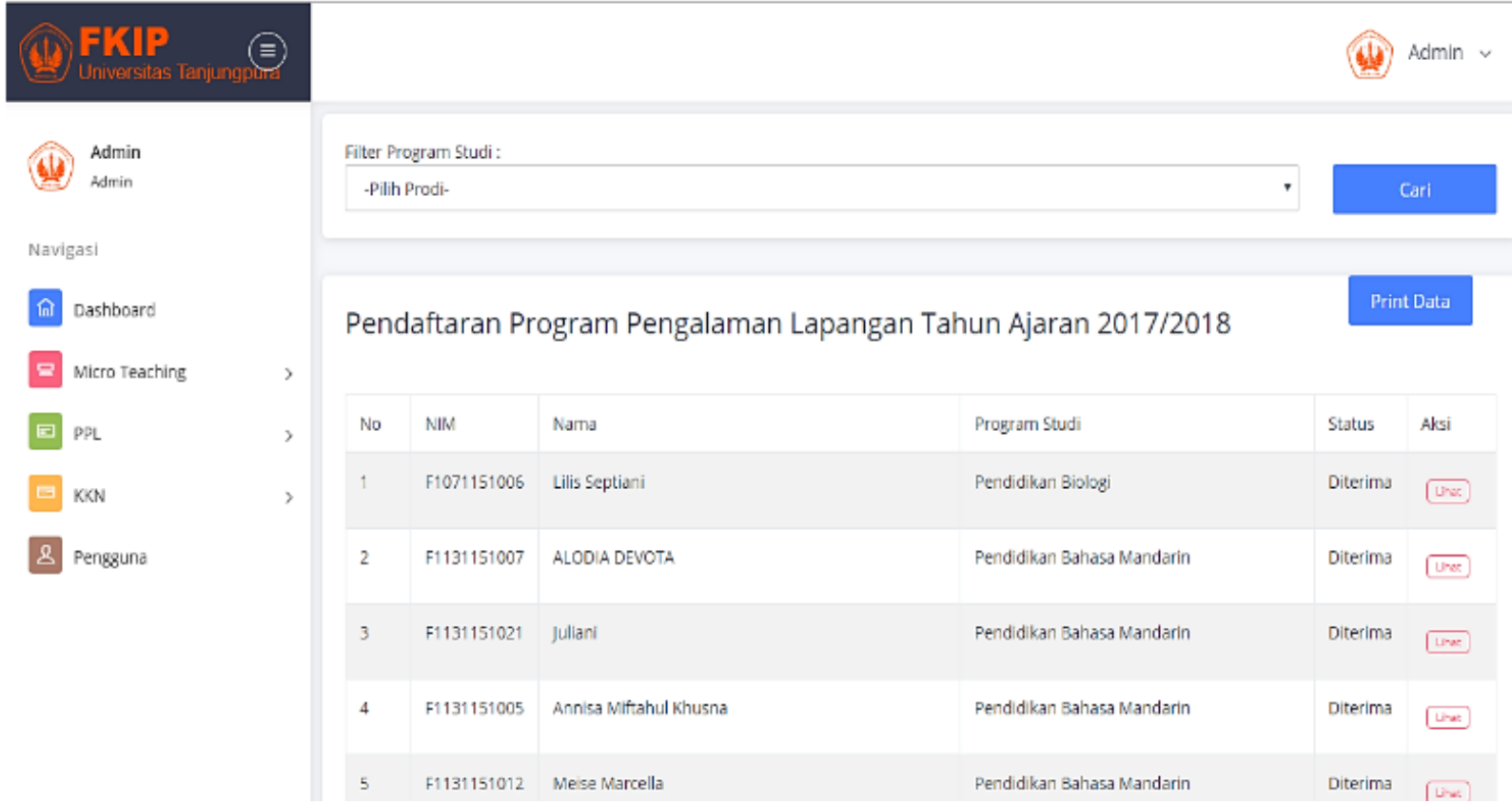

Gambar 7. Tampilan muka administrator saat verifikasi berkas pendaftar 
Tampilan pengecekan persyaratan kegiatan PPL dengan cek mata kuliah Mikro Teaching disajikan pada Gambar 8. Apabila mahasiswa lulus mata kuliah tersebut maka verifikasi diterima dan jika tidak lulus mata kuliah tersebut maka verifikasi ditolak.

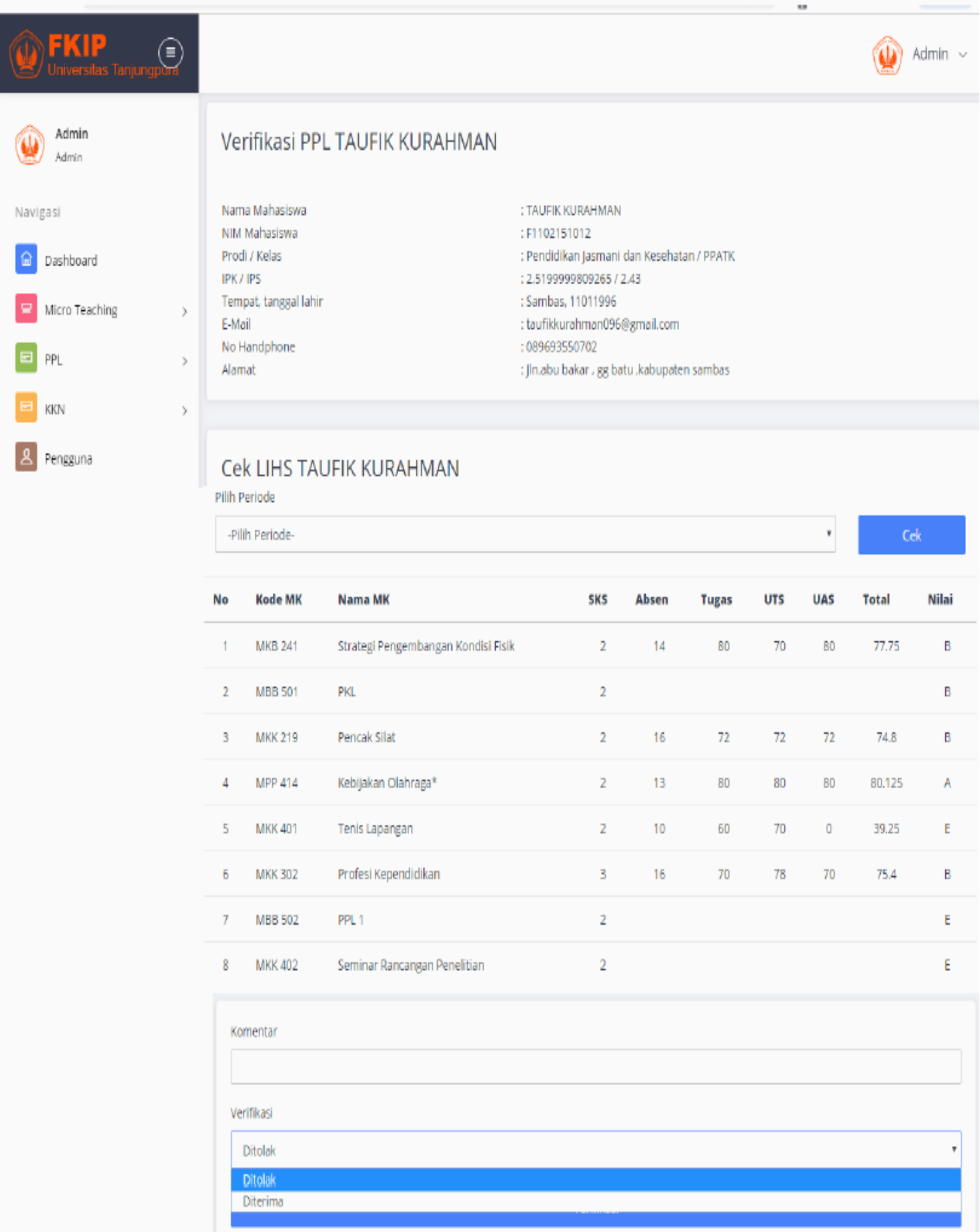

Gambar 8. Proses verifikasi persyaratan peserta kegiatan PPL 
Tampilan muka pengumaman hasil verifikasi oleh pendaftaran disajikan pada Gambar 8 . Selanjutnya, hasil verifikasi tersebut juga disampaikan ke alamat email seperti pada Gambar 9.

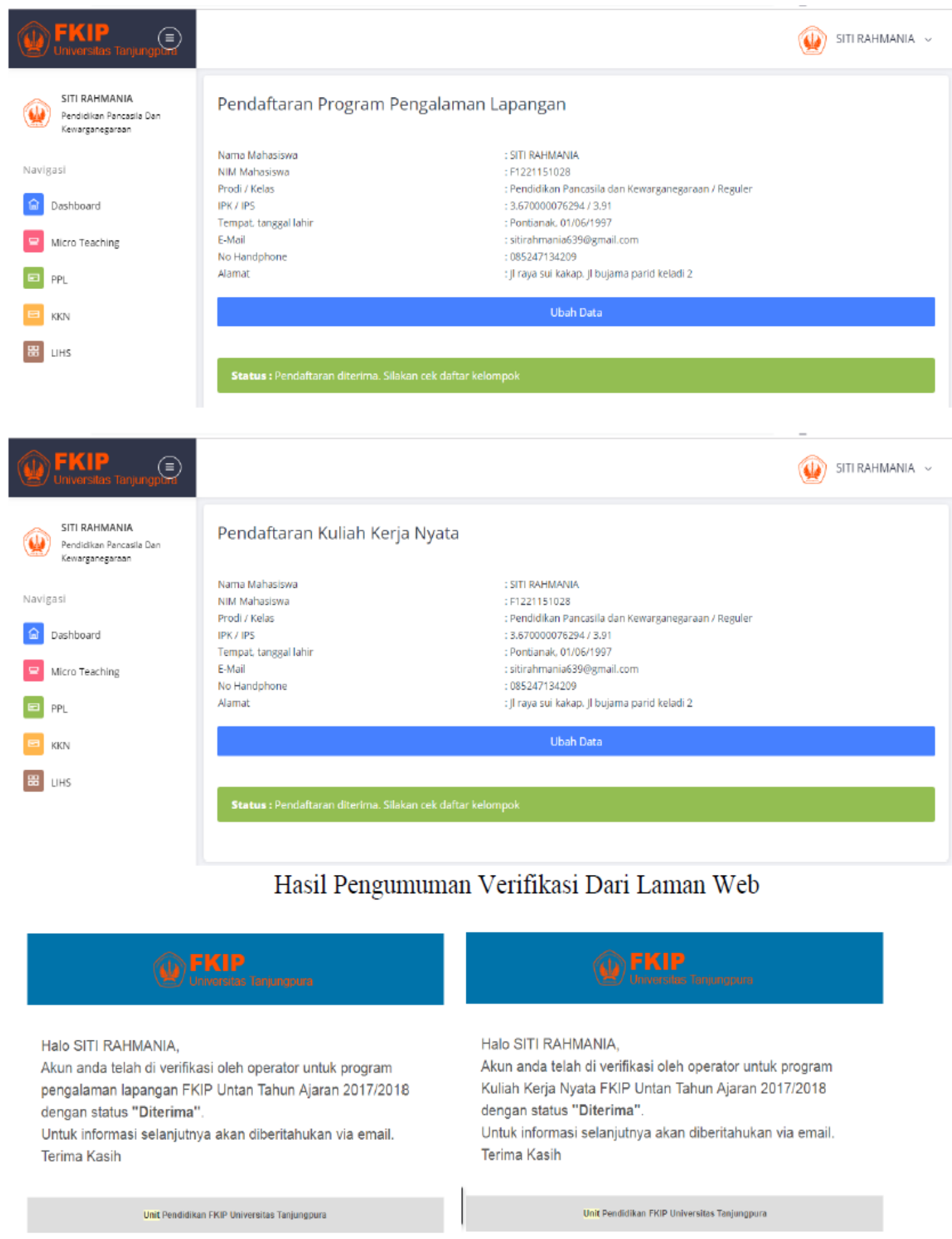

Hasil Pengumuman Verifikasi dari Email Pendaftar

Gambar 9. Hasil pengumuman verifikasi dari situs web dan email pendaftar 


\section{Validasi Web}

Validasi web bertujuan untuk untuk melihat kesesuaian antara web dengan tahapan pendaftaran, kemudahan akses peserta, pertahanan sistem web dari virus dan pembobol data dengan melibatkan tiga orang validator dari pengelolah unit teknologi dan informasi (Unit TIK) FKIP Untan. Hasil yang diperoleh dari tahap valiadi disajikan pada Tabel 3. Berdasarkan Tabel 3 tersebut diketahui bahwa validator menyatakan bahwa web yang dikembangkan valid dan layak digunakan dalam proses pendaftaran.

Tabel 3. Hasil validasi web pendaftaran kegiatan PPL dan KKN

\begin{tabular}{clcc}
\hline No & \multicolumn{1}{c}{ Pernyataan } & Rerata & Keterangan \\
\hline 1 & $\begin{array}{l}\text { Desain sistem memiliki desain simpan data pendaftar } \\
\text { Kegiatan PPL dan KKN. }\end{array}$ & 3,2 & Valid \\
2 & $\begin{array}{l}\text { Desain sistem memiliki desain simpan data pendaftar yang } \\
\text { lulus verifikasi pada kegiatan PPL dan KKN. }\end{array}$ & 3,7 & Valid \\
3 & $\begin{array}{l}\text { Desain sistem memiliki desain simpan data pendaftar yang } \\
\text { tidak lulus verifikasi pada Kegiatan PPL dan KKN. }\end{array}$ & 3,7 & Valid \\
4 & $\begin{array}{l}\text { Desain sistem mudah digunakan baik pendaftar dan } \\
\text { administrator. }\end{array}$ & Valid \\
5 & $\begin{array}{l}\text { Desain sistem mudah diakses bagi calon pendaftar (khusus } \\
\text { mahasiswa FKIP Untan). }\end{array}$ & 3,6 & Valid \\
6 & $\begin{array}{l}\text { Desain sistem memiliki ketahanan terhadap pembobolan data } \\
\text { peserta yang lulus verifikasi PPL dan KKN. }\end{array}$ & 3,2 & Valid \\
7 & $\begin{array}{l}\text { Desain sistem memiliki ketahanan terhadap penyerangan virus } \\
\text { dan atau malwere. }\end{array}$ & 3.5 & Valid \\
8 & $\begin{array}{l}\text { Desain sistem memiliki desain yang memproteksi penggunaan } \\
\text { sandi pada saat login. }\end{array}$ & 3,1 & Valid \\
\hline
\end{tabular}

\section{Uji Coba Web Pada Proses Pendaftaran}

Uji coba web digunakan pada calon peserta kegiatan PPL dan KKN FKIP Untan tahun ajaran 2018/2019 dengan diambel sampel acak sebanyak 100 dari 1415 total pendaftar. Adapun hasil yang diperoleh disajikan pada Tabel 4. Berdasarkan Tabel 4 tersebut diketahui bahwa calon peserta kegiatan PPL dan KKN FKIP Untan yang mendaftar melalui situs web yang telah dikembangkan memberikan respon positif yang tinggi terhadap penggunaan web dalam proses pendaftarannya. 
Tabel 4. Hasil Uji Penggunaan Website Kepada Pendaftar Kegiatan PPL dan KKN

\begin{tabular}{clcc}
\hline No & \multicolumn{1}{c}{ Pernyataan } & Rerata & Keterangan \\
\hline 1 & Web pendaftaran mudah digunakan & 4,1 & Tinggi \\
2 & $\begin{array}{l}\text { Web pendaftaran memakan waktu pendaftaran yang relatif } \\
\text { singkat }\end{array}$ & 4,7 & Tinggi \\
3 & Web pendaftaran memberikan informasi data yang tepat & 4,7 & Tinggi \\
4 & $\begin{array}{l}\text { Web pendaftaran mudah diakses kapanpun dan dimanapun } \\
\text { berada }\end{array}$ & 4,5 & Tinggi \\
5 & Web pendaftaran memudahkan proses pendaftaran & 4,9 & Tinggi \\
\hline
\end{tabular}

\section{Pembahasan Hasil Pengembangan, Validasi dan Uji Coba}

Penggunaan sistem pendaftaran kegiatan PPL dan KKN terdiri dari administrator dan pendaftar. Pendaftar adalah mahasiswa yang berkeinginan mengikuti kegiatan PPL dan KKN sebagai mata kuliah wajib untuk seluruh mahasiswa di lingkungan FKIP Untan. Peran pendaftar dalam web ini adalah pengisian data terkait kegiatan PPL dan KKN. Peran administrator dalam web pendaftaran ini adalah sebagai verifikator, yaitu memverifikasi persyaratan pendaftar kegiatan PPL dan KKN, menerima peserta kegiatan PPL dan KKN dari pendaftar yang memenuhi persyaratan dan menolak pendaftar yang tidak memenuhi persyaratan dalam mengikuti kegiatan PPL dan KKN.

Dalam pengembangan web, digunakan bahasa pemprograman PHP dengan basis data MySQL. Penggunaan bahasa pemprograman tersebut banyak digunakan sebagai dasar pengembangan web. Aprida dan Samopa (2013) serta Ramadhani dkk (2013) dalam pengembangan webnya menggunakan pemprograman PHP dan dengan basis data MySQL memudahkan dalam pembuatan web karena PHP dan MySQL di dapat secara gratis, mudah digunakan dan kesalahan eror relatif lebih kecil terutama pada saat melakukan coding. Hal yang sama dialami selama masa pembuatan web, dimana pada tahap Testing menggunakan Black-Box semua dapat berjalan dengan baik.

Setelah web dikembangkan, langkah selanjutnya memvalidasi web dengan melibatkan pakar di bidang IT dan diperoleh hasil bahwa web yang dikembangkan valid. Hasil validasi tersebut menunjukkan bahwa web yang dikembangkan memiliki kemudahan pengoperasian, kemudahan akses dan sistem pertahanan terhadap virus dan pembobolan data. Menurut Rahadi (2011) sebuah website yang dikembangkan harus memiliki atribut-atribut meliputi kenyamanan akses, desain yang menarik, keamanan dan bersifat informatif serta mudah dioperasikan 
sehingga membuat pengguna merasa puas terhadap pelayanan yang diberikan dari penggunaan website tersebut. karena website yang dikembangkan memenuhi atribut-atribut tersebut sehingga pada saat uji penggunaan website memperoleh respon positif terhadap pengguna, terutama pendaftar yang mendaftarkan dirinya melalui website yang dikembangkan.

Hasil pengembangan website memudahkan mahasiswa mendaftar kegiatan PPL dan KKN sebagai mata kuliah wajib untuk mahasiswa di lingkungan FKIP Untan. Selain itu pihak pengelolah kegiatan PPL dan KKN yang bertindak sebagai administrator dapat meningkatkan mutu pelayanan. Dari hasil penerapan website dapat meringkas waktu pendaftaran, menghemat penggunaan kertas sebagai formulir pendaftaran serta dapat melakukan verifikasi persyaratan dengan tepat dan berkesesuaian dengan data SIAKAD Untan yang secara langsung diintegrasikan ke dalam sistem website yang dikembangkan. Hal ini menyababkan pengambilan keputusan peserta dari kegiatan PPL dan KKN menjadi tepat dan sesuai dengan ketentuan persyaratan yang berlaku.

\section{SIMPULAN}

Berdasarkan hasil penelitian yang telah dilakukan maka dapat disimpulkan bahwa website pendaftaran yang dikembangkan dengan model System Development Life Cycle (SDLC) dengan bentuk waterfall memiliki kevalidan yang tinggi dan pengguna memberikan respon positif terhadap proses pendaftaran peserta PPL dan KKN. Pengguna website terdiri dari dua kategori yaitu pendaftar dan administrator. Pendaftar merupakan mahasiswa yang berkeinginan mengikuti kegiatan PPL dan KKN, sedangkan administrator berperan untuk memverifikasi persyaratan pendaftar agar dapat mengikuti kegiatan PPL dan KKN.

\section{DAFTAR PUSTAKA}

Alfaris, H.B., Anam, C., \& Masy'an, A. (2013). Iimplementasi black box testing pada sistem informasipendaftaran santri berbasis web dengan menggunakan PHP dan MySQL. Saintekbu: Jurnal Sains dan Teknologi 6(1).

Aprida, C.D., \& Samopa, F. (2013). Pembuatan sistem informasi beasiswa internal direktorat jendral perbendaharaan menggunakan PHP dan MySQL. Jurnal Teknik Pomits 2(2). 
Rahadi, D. R. (2011). Pengaruh karakteristik website terhadap kepuasan pelanggan. Jurnal Teknologi Informasi 1(1).

Ramadhani, S., Anis, U., \& Masruro, S.T. (2013). Rancang bangun sistem informasi geografis layanan kesehatan di kecamatan lamongan dengan PHP dan MySQL. Jurnal Teknika Tahun 5 (2).

Standsyah, R.E., \& Restu I.S. (2017). Implementasi phpmyadmin pada rancangan sistem pengadministrasian. Unisda Journal of Mathematics and Computer Science. 3(3).

Youssef, B. (2012). A simulation model for the waterfall sofware development life cycle. International Journal of Enggineering and Technology (IJET), 2(5), 1-7. 